\title{
Analysis of Gram negative recolonization of the neuropathic bladder among patients with spinal cord injuries
}

\author{
WH Donovan ${ }^{1,3}$, R Hull ${ }^{2}$ and CD Rossi ${ }^{1,2}$ \\ ${ }^{1}$ The Institute for Rehabilitation and Research , ${ }^{2}$ Baylor College of Medicine and the ${ }^{3}$ University of Texas Medical \\ School, Houston, USA
}

Over a 4 year period, 119 acute spinal cord injury (SCI) patients were enrolled in this study. The 101 males and 18 females had a mean age of 35.9 years (range 16-87). Sixty-two patients were tetraplegic and 57 were paraplegic. All patients had a urine specimen taken for culture, colony count and sensitivity once weekly while they were receiving intermittent catheterization. Of these, 22 patients $(18.5 \%)$, none of whom had underlying genito-urinary (GU) pathology, developed recolonization by an organism of the same species and genus previously cultured. All 22 reached sterile urine between colonizations after being treated with antibiotics for at least 7 days. The 16 males and six females had a mean age of 35.1 years (range 17-79). Sixteen were tetraplegic and six were paraplegic.

Plasmid analysis (PA) was used to determine whether these recolonizations were from the same or from a different strain. In those instances where the bacteria harbored no plasmids or where the results of plasmid analysis were otherwise inconclusive, bacteria were also compared using restriction fragment length polymorphism (RFLP) analysis. Recolonization was caused primarily by $E$. coli and $K$. pneumoniae. While there was no significant difference between the two organisms with respect to the number of days when sterile urine occurred to the time when recolonization was observed, there were significant differences seen in both organisms with regard to the time lapse from one colonization to the next: the average number of days to recolonization with an identical organism was 10.3 days, whereas with a different strain it was 15.9 days $(P<0.04)$. When a different organism was cultured between the recolonizations, the mean recolonization interval was 17.9 days. When no intervening organism occurred, the interval was 9.5 days $(P<0.005)$. Both intervals measured the days from the first sterile urine after the first colonization to the next colonization.

These data indicate the proclivity for two common Gram negative normal bowel inhabitants to recolonize the neuropathic bladder of spinal cord injured patients even after adequate treatment. PA and RFLP provide a means of discriminating between relapses by the same organism versus recurrences by a different organism of the same species and genus. Those with the same identity tend to recur sooner than those of different identities and may be suspected when relapse occurs within two weeks of cessation of 7 day course of antibiotics. While an intervening organism may delay the relapse (or recurrence), it does not prevent it and identical organisms can reappear even after adequate therapeutic regimens.

Since none of the patients in this study had GU pathology, recolonization by an identical strain (relapse) does not necessarily warrant an extensive investigation for disease within the GU tract.

Keywords: spinal cord injury; neuropathic bladder; plasmid analysis; restriction fragment length polymorphism; bacteriuria

\section{Introduction}

Urinary tract infections (UTI) remain a significant problem for the spinal cord injured (SCI) patient throughout his or her life and a major cause of morbidity. ${ }^{1}$ Despite the advantages that have accrued from the use of intermittent catheterization (IC) as part of the acute and long term management of SCI

Correspondence: WH Donovan patients, urinary colonization and infections continue to occur in many individuals. ${ }^{2 .} 7$ Often, the patients may remain asymptomatic and recommendations have been made that such asymptomatic bacteriuria in the SCI neurpathic bladder should not be treated. ${ }^{2}$ Opinions differ however as to what constitutes symptomatic and asymptomatic bacteriuria. Nevertheless, even when bacteriuria is regarded by the clinician as symptomatic enough to be treated for 7 
to 14 days, re-colonization, even with the same organism, can occur. Recolonization by the identical strain has been referred to as relapsing bacteriuria and can have different implications from recolonization by a completely different strain, often referred to as recurrent bacteriuria. ${ }^{8}$ Such implications include genitourinary (GU) diseases like nephrolithiasis or cystolithiasis, chronic prostatitis and chronic pyelonephritis. Difficulty with making the differentiation between relapsing and recurrent bacteriuria arises when the clinical laboratory reports that a patient is recolonized with an organism of the same genus and species as the one previously, because the strain may be different even though the genus/species are the same but the laboratory is usually not able to make this distinction. Recently the authors have described a methodology using plasmid analysis (PA) to determine whether re-colonization of the neuropathic bladder by the same genus/species actually represents relapsing bacteriuria or just recolonization by a different strain of the same genus/species. In that study, it was shown that a common bowel inhabitant (Klebsiella pneumoniae), was capable of recolonizing the neuropathic bladder of SCI patients when the identical strain was found in the bowel and then in the urine on repeated occasions. Plasmid analysis was also able to differentiate whether the recolonizing organisms were relapsing or recurrent and indicated that the organisms within the bowel may serve as a reservoir for relapsing bacteriuria. ${ }^{8}$ In the present study we wanted to learn whether and which other Gram negative bacteria were capable of causing relapsing bacteriuria in the SCI urinary tract as well and what clinical implications might be drawn.

\section{Materials and methods}

\section{Patient population}

Over a 4 year period (1990-1994) 119 recently injured spinal cord patients were enrolled in this study. The 101 males and 18 females had a mean age of 35.9 years (range 16-87). Sixty-two patients tetraplegic and 57 were paraplegic. All patients had a urine specimen taken for culture, colony count and sensitivity once weekly while they were being treated with intermittent catheterization using the MMG O'Neill catheter. Intermittent catheterizations were performed 4-6 times daily using sterile technique. The urine specimens were plated on appropriate bacteriological media and subsequent bacterial growth with greater than 100,000 colony forming units (CFU) was identified in the conventional manner. Two colonies of each Gram negative bacterial colonization of the neuropathic bladder that occurred in any of these patients were stored in $30 \%$ glycerol $-1 \%$ peptone at $-70^{\circ} \mathrm{C}$. When an episode of bacteriuria was felt by the attending physician to have sufficient symptoms such as fever, incontinence, augmentation of spasticity etc., to warrant treatment, that patient was tracked for the following parameters: duration of antibiotic treatment (selected from the antibiogram), when sterile urine was achieved and whether recolonization occurred. When recolonization with the same genus/species did occur, both the original urine specimen and the second specimen underwent PA to determine whether the organisms were identical. Plasmid analysis was performed according to methods previously described. ${ }^{8}$ When PA was inconclusive, ie, for those bacteria that had no plasmids, the organisms were then further tested using pulsed-field gel electrophoresis (PFGE). This process examines all of the DNA material rather than only the plasmids. It relies on restriction fragment length polymorphism (RFLP) in the genome of the test strain and is independent of plasmid content. DNA fingerprinting using PFGE RFLP technology has been used for epidemiological studies in a variety of organisms. ${ }^{9} \quad 11$

\section{Specimen preparation}

Plasmid purification: Plasmid DNA was purified from urinary isolates using the alkaline lysis method described by Portnoy. ${ }^{22}$ Bacteria were grown overnight in $5 \mathrm{ml} \mathrm{L}$ broth. One $\mathrm{ml}$ of culture was centrifuged and the bacterial pellet was resuspended in $40 \mu \mathrm{l} T E\left(10 \mathrm{mM} T_{\mathrm{ris}}{ }^{1}, 1 \mathrm{mM} E_{\mathrm{DTA}}{ }^{2}, \mathrm{pH} 8.0\right)$. Cells were lysed by addition of $600 \mu \mathrm{l}$ of fresh lysis buffer $(50 \mathrm{~mm}$ Tris, $10 \mathrm{mM}$ EDTA, $4 \%$ sodium dodecyl sulfate (SDS), $\mathrm{pH} 12.40-12.45$ ). The samples were then neutralized by addition of $30 \mu \mathrm{l} 2 \mathrm{M}$ Tris (pH 7.0) followed by thorough mixing. Single stranded chromosomal DNA was precipitated by addition of $160 \mu \mathrm{l}$ of $5 \mathrm{M} \mathrm{NaCl}$ followed by $1 \mathrm{~h}$ incubation on ice. Samples were then centrifuged at $12,500 \mathrm{~g}$ for $5 \mathrm{~min}$. The supernatant was collected and the plasmid DNA was precipitated by addition of $550 \mu \mathrm{l}$ of isopropanol followed by incubation at $-20^{\circ} \mathrm{C}$ for at least $1 \mathrm{~h}$. The DNA was then collected by centrifugation and resuspended in $30 \mu \mathrm{l}$ of TE. Ten microliter samples were used for agarose gel electrophoresis analysis on $0.7 \%$ Tris-Borate gels. ${ }^{13}$

DNA preparation for transverse alternating field electrophoresis (TAFE) ie., a form of PFGE: Bacteria were grown overnight in $3 \mathrm{ml}$ of $\mathrm{L}$ broth. One $\mathrm{ml}$ of culture was centrifuged and the bacterial pellet resuspended in $1 \mathrm{ml}$ EET $(100 \mathrm{mM}$ EDTA, $10 \mathrm{mM}$ $E_{G^{2}}^{3}, 10 \mathrm{mM}$ Tris, $\mathrm{pH} 8.0$ ) buffer. Four hundred microliters of bacteria were mixed with $400 \mu \mathrm{l}$ molten $\left(50^{\circ} \mathrm{C}\right)$ InCert agarose (FMC Byproducts, Rockland, MD). This was added to a plug casting mould (Beckman Instruments, Fullerton, CA), and allowed to solidify at $4 . \mathrm{C}$ for $30 \mathrm{~min}$. The agar plugs containing bacteria were then incubated at room temperature for $2 \mathrm{~h}$ in $12 \times 75 \mathrm{~mm}$ plastic culture tubes containing $4 \mathrm{ml}$ of lysozyme solution $(200 \mathrm{mg} /$ $\mathrm{ml}$ egg white lysozyme, $0.05 \%$ sodium lauryl sarcosine). The lysozyme solution was removed, replaced with $4 \mathrm{ml}$ of lysis solution $(100 \mu \mathrm{g} / \mathrm{ml}$ of proteinase $\mathrm{K}, 1 \% \mathrm{SDS}$ in EET buffer), and incubated 
overnight at $50^{\circ} \mathrm{C}$. The plugs were then transferred to a plastic Petri dish containing $25 \mathrm{ml}$ of stop solution (100 mM of phenylmethylsulfonyl fluoride in TE) and incubated $1 \mathrm{~h}$ at room temperature. The stop solution was removed and the plugs were washed four times for $1 \mathrm{~h}$ each time with $25 \mathrm{ml}$ of TE. Finally the plugs were transferred to a $12 \times 75 \mathrm{~mm}$ plastic culture tube containing $4 \mathrm{ml}$ of $\mathrm{TE}$ and stored at $4{ }^{\circ} \mathrm{C}$ prior to use. For RFLP analysis, a sample of the DNA encased in agar was cut from a plug and incubated overnight with restriction endonuclease in $200 \mu$ ldigestion buffer supplied by the enzyme manufacturer. DNA restriction fragments were analyzed using a GeneLine II TAFE system (Beckman Instruments, Fullerton, CA).

\section{Results}

Of the 119 patients enrolled in this study, $22(18.5 \%)$ developed recolonization of their urinary tracts by an organism of the same genus/species cultured previously. All 22 had at least one sterile urine between colonizations whilst off antibiotics, after they had been treated for at least 7 days with antibiotics chosen on the basis of culture and sensitivities. The sixteen males and six females had a mean age of 35.1 years (range 17-79). Sixteen were tetraplegic and six were paraplegic.

Organisms representing only four genera contributed to 34 recolonizations in these 22 patients (Table 1). The most commonly found organism was $K$. pneumoniae followed by $E$. coli, $S$. marcescens and $P$. mirabilis. Urinary tract colonization with other Gram negative bacteria including Acinetobacter sp., Pseudomonas sp., Enterobactor sp. and Citrobacter sp. was also observed but recolonization did not occur. The time between the first and the second colonization was measured from the date of the first sterile urine obtained after treatment for the first colonizations. This first sterile urine was usually noted 2 weeks after the discovery of the first colonization. The mean time from this first sterile urine after completion of treatment to the second colonization is shown in Table 1. There was no significant difference between the four organisms with respect to the number of days it took for sterile urine to occur or when recolonization was observed. These 34 recolonizations by

Table 1 Influence of the identity of the bacterial genus/ species upon the time in days after sterile urine achieved and repeat urinary tract colonization by that same genus

\begin{tabular}{lccc}
\hline $\begin{array}{l}\text { Bacterial genus } \\
\text { species }\end{array}$ & $\begin{array}{c}\text { Number of } \\
\text { recurrences }\end{array}$ & Mean time & Range \\
\cline { 2 - 4 } K. pneumoniae & 22 & 13.5 & $7-35$ \\
E. coli & 9 & 11.2 & $7-35$ \\
S. marcescens & 2 & 17.0 & $12-22$ \\
$P$. mirabilis & 1 & 7.0 & N/A \\
Total & 34 & & \\
\hline
\end{tabular}

organsims with the same genus/species were then compared to eighteen episodes of recurrent bacteriuria consisting of recolonization by different genus/ species that occurred at different times during the course of hospitalization in these same 22 patients. There were no significant differences in the time that it took bacteria to recolonize whether they were of the same or different genus/species (Table 2).

When the 34 recolonizations were then grouped according to whether they were relapsing or recurrent, based on either PA or RLFP, 18 were relapsing and 16 recurrent. The difference between the mean time from sterile urine to identification of a recolonization in these two groups, just reached the level of significance $(P>0.04)$. The mean time for relapsing bacteria was 10.3 days and for recurrent bacteria it was 15.9 days (Table 3). When the 34 recolonizations were next grouped according to whether an intervening organism had inhabited the bladder in between the recolonizations, it was found as expected, that the intervening organism delayed the recolonization of the original genus/species. Intervening organisms included Acinetobactor sp., Enterococcus faecalis, Staphytococcus sp. and Streptococcus sp. The difference was significant at $P>0.005$ (Table 4). Twenty recolonizations did not have an intervening organism between the first and second occurrences while $14 \mathrm{did}$. Of the 20 recolonizations without an intervening organism, 13 were relapses and seven were recurrences. Of the fourteen recolonizations that did have an intervening organism, only five were relapses and nine were recurrences (Table 5). The difference betwen relapses without an intervening organisms versus those with intervening organisms, failed to reach statistical significance, ie,

Table 2 Average time in days after sterile urine achieved until the next urinary tract recolonization with bacteria of the same or different genus/species

\begin{tabular}{lccc} 
& $\begin{array}{c}\text { Number of } \\
\text { colonization } \\
\text { pairs }\end{array}$ & Mean time & Range \\
Genus/species & 34 & 12.9 & $7-35$ \\
Same & 18 & 12.4 & $7-28$ \\
\hline Different & & &
\end{tabular}

Table 3 Average time in days after sterile urine achieved until the next episode of relapsing urinary tract colonization (same genus/species, same strain) versus recurrent colonization (same genus/species, different strain)

\begin{tabular}{lccc}
\hline $\begin{array}{c}\text { Colonization } \\
\text { type }\end{array}$ & $\begin{array}{c}\text { Number of } \\
\text { repeat } \\
\text { colonizations }\end{array}$ & Mean time ${ }^{a}$ & Range \\
\hline Relapsing & 18 & 10.3 & $7-22$ \\
Recurrent & 16 & 15.9 & $7-35$ \\
Total & 34 & & \\
\hline${ }^{a} P<0.04$, relapsing versus recurrent &
\end{tabular}


Table 4 Influence of intervening organisms upon the time in days after sterile urine achieved and urinary tract recolonization by the same genus

\begin{tabular}{lccc}
\hline $\begin{array}{l}\text { Intervening } \\
\text { organism }\end{array}$ & $\begin{array}{c}\text { Number of } \\
\text { recolonizations }\end{array}$ & Mean time $^{c}$ & Range \\
\hline Absent $^{\mathrm{a}}$ & 20 & 9.5 & $7-21$ \\
Present $^{\mathrm{b}}$ & 14 & 17.9 & $7-35$ \\
\hline
\end{tabular}

"Indicates that episodes of urinary tract colonization with bacteria of the same genus/species were separated by intervals of sterile urine. ${ }^{\mathrm{b}}$ Indicates that episodes of urinary tract colonization with bacteria of the same genus/species were separated by an interval of sterile urine, an episode of colonization with organisms of a different genus species, then sterile urine, then recolonization. ${ }^{\mathrm{c}} P<0.005$, absent versus present

Table 5 Influence of intervening organisms upon the frequency of relapsing urinary tract colonization

\begin{tabular}{lcc}
\hline $\begin{array}{l}\text { Intervening } \\
\text { organism }\end{array}$ & $\begin{array}{c}\text { Number of } \\
\text { recolonizations }\end{array}$ & $\begin{array}{c}\text { Number that } \\
\text { were relapses }\end{array}$ \\
\hline Absent & 20 & 13 \\
Present & 14 & 5 \\
Total & 34 & 18 \\
\hline${ }^{a} P$ is NS &
\end{tabular}

Table 6 Correlation between PA/RFLP results and antibiogram

\begin{tabular}{lcc}
\hline $\begin{array}{l}\text { Method of } \\
\text { analysis }\end{array}$ & Result \\
\hdashline Identical & Different \\
PA/RFLP & 18 & 17 \\
Antibiogram & 16 & 17 \\
\hline$r=0.94(P<0.001)$ & - &
\end{tabular}

$P=0.09$ (Table 5). The alpha level of 0.05 was chosen for all statistical analyses in the study. Since it is realized that most clinical laboratories will not have PA or RFLP to help make the determination as to relapsing versus recurrent bacteriuria, the results of PA/RFLP were compared to an analyses of the antibiograms for each recolonization pair. The antibiograms agreed with the PA/RFLP in all but one case $(r=0.94, P<0.001)$ (Table 6$)$.

\section{Discussion}

These data indicate the proclivity for two common Gram negative, normal bowel inhabitants to recolonize the neuropathic bladder of spinal cord injured patients. It was found in this study to occur in nearly $20 \%$ of all SCI patients treated with IC. PA and RFLP as well as the clinical antibiogram provide a means for discriminating between relapses by the same organisms versus recurrences by a different strain of the same genus/ species. This discrimination is of some clinical importance since repeated urinary tract colonizations with the same genus/species are often presumed to be relapsing bacteriuria. Relapsing bacteriuria may indicate an abnormality within the urinary tract such as calculus, a urethral/vesical diverticulum or chronic prostatitis. However, recolonization occurred in $18.5 \%$ of the 119 patients enrolled in this study, all of whom had absence of any GU pathology and $53 \%$ of these 22 had a reemergence of the identical strain of bacteria. Further, 16 of $34(47 \%)$ recolonizations by the same genus/species were in fact entirely different strains and therefore their recolonizations bore no such implications. Thus as previous work has shown, ${ }^{8}$ recolonization by the same genus/species, even when both colonizations are of identical strain does not necessarily signify the presence of GU pathology. When the abnormal conditions mentioned have been ruled out, this work supports a previous conclusion that patients with recolonization of the urinary tract can be managed expectantly if they are asymptomatic or with the appropriate antibiotic if symptomatic.

Those recolonizations that are relapsing tend to recur sooner than those of different strains and may be suspected when relapse occurs within 2 weeks of the cessation of a 7 day course of antibiotics. While an intervening organism may delay a recolonization, it does not necessarily prevent it and identical organisms may reappear even after effective treatment has been carried out for both the original organism and the intervening one.

Why these relapses occur is open to question. One possibility is that the bowel serves as a reservoir for these organisms. The organisms may spread from the perianal area to the meatus of the urethra and be introduced during the intermittent catheterization technique. If this were the case, one would expect that more attention to the detail of preparation for catheterization such as aggressive perineal hygiene, and/or better catheterization techniques would reduce the frequency of all recolonizations, not just those of the same genus/species. ${ }^{8} 14$ Bennett reported a higher incidence of bacterial colonization with $E$. coli in women and believed this may be explained by closer bowel-urethral proximity in females. ${ }^{4}$ In the present study, no significant differences between males and females were found with regard to the incidence of initial colonizations or recolonizations with $E$. coli or $K$. pneumoniae $(P=0.09)$.

A second possibility is that the bacteria involved in the recolonizations, primarily $E$. coli and $K$. pneumoniae, have bacterial bio-films that are capable of surrounding the bladder epithelium and the antibiotics chosen were ineffective in penetrating the bio-films and removing the bacteria. ${ }^{15}$ In this regard the authors noted no apparent differences between antibiotics chosen as to the recurrences of these organisms in this study. Prophylactic antibiotics were not used.

In any event, those relapsing recolonizations that were harbored within the host between recolonizations were somehow protected from the antibiotics to which they were sensitive. 


\section{Conclusions}

Depsite the advantages of using intermittent catheterization during the acute phase of rehabilitation, patients were still vulnerable to bacterial colonization of the urinary tract. Recolonization of the acute SCI neuropathic bladder by the same genus/species may also occur and be due to identical (relapsing) or different (recurrent) strains. PA and RFLP permit precise determination of these two entities. In this series just over half $(53 \%)$ of the recolonizations were due to an identical strain even in the absence of GU pathology. Recolonization by the same strain tends to recur sooner than those of different strains. Growth of an intervening organism between recolonizations by the same genus delays the genus' reappearance but does not prevent it and may only mask its persistence.

While recolonizations with no intervening organism between them were more likely to be identical (relapsing bacteriuria) this did not reach statistical significance $(P=0.09)$. Nevertheless $5 / 14 \quad(36 \%)$ of recolonizations following an intervening organism were relapses. Thus if relapses indicate persistence of an organism within the host, even two courses of effective antibiotics may not remove it. These data support the theory that when patients are managed by intermittent catheterization and treated for bacteriuria, certain bacteria may remain within the body untouched by antibiotics and then recolonize the bladder. The clinician may rely on the antibiogram to determine whether a particular recolonization by the same genus/species is due to an identical strain or not.

\section{References}

1 Cardenas DD, Farrell-Roberts L, Sipski ML, Rubner D. Management of gastrointestinal, genitourinary and sexual function in spinal cord injury In: Stover SL, DeLisa JA, Whiteneck GG (eds.) Spinal Cord Injury - Outcomes from the Model System, Aspen Publishing, Inc: Gaithersburg, Md, 1995 pp. $126-136$.
2 Erickson RP, Merritt JL, Opitz JL, Illstrup DM. Bacteriuria during follow-up in patients with spinal cord injury; rates of bacteriuria in various bladder emptying methods. Arch of Phy Med and Rehab 1982; 63: 409-412.

3 McGuire EJ, Savastano JA. Long term followup of spinal cord injury patients managed by intermittent catheterization. $J$ Urol 1983; 129: $775-776$.

4 Lloyd LK, Kuhlemier KV, Fine PR, Stover SL. Initial bladder management in spinal cord injury: does it make a difference? $J$ Urol 1986; 135: 523-527.

5 Perkash I, Giroux J. Prevention, treatment and management of urinary tract infection in neuropathic bladders. J Am Para Soc 1974; 8: $15-17$.

6 Donovan WH, Stolov WC, Clowers DE, Clowers MR. Bacteriuria during intermittent catheterization following spinal cord injury. Arch of Phy Med and Rehabil 1978; 59: 351-357.

7 National Institute on Disability and Rehabilitation Research (NIDRR) Consensus Statement. The Prevention and Management of urinary tract infections among people with spinal cord injuries. J Am Paraplegia Soc 1992; 15: 194-207.

8 Donovan WH et al. Use of plasmid analysis to determine the source of bacterial invasion of the urinary tract. Paraplegia 1990; 28: $573-582$.

9 Tenover FC et al. Interpreting chromosomal DNA restriction patterns produced by pulsed-field gel electrophoresis: criteria for bacterial strain typing. J Clin Micro 1995; 33: 2233 - 2239.

10 Najdenski H, Iteman I, Carniel E. Efficient subtyping of Yersinia enterocolitica strains by pulsed-field gel electrophoresis. J Clin Micro 1994; 32: 2913-2920.

11 Mahalingam S et al. Molecular epidemiologic analysis of Vibrio cholera $\mathrm{O} 1$ isolated by pulsed-field gel electrophoresis. J Clin Micro 1994; 32: $2975-2979$.

12 Portnoy DA, Moseley SL, Falkow S. Characterization of plasmids and plasmid-associated determinants of Yersinia enterocolitica pathogenesis. Infection and Immunity 1994; 31: $775-782$.

13 Sambrook J, Fritsch EF, Maniatis T. Molecular cloning. 2nd Ed. Cold Spring Harbor Laboratory Press, 1989.

14 Bennett CJ, Young MN, Darrington H. Differences in urinary tract infections in male and female spinal cord injury patients on intermittent catheterization. Paraplegia 1995; 33: 69-72.

15 Reid G et al. Use of adhesion counts to help predict symptomatic infection and the ability of fluoroquinolones to penetrate bacterial biofilms on the bladder cells of spinal cord injured patients. Paraplegia 1994; 32: $468-472$. 